\title{
Validation of RNA isolated from milk fat globules to profile mammary epithelial cell expression during lactation and transcriptional response to a bacterial infection
}

\author{
P. Brenaut, ${ }^{\star}$ R. Bangera, + C. Bevilacqua, ${ }^{*} \ddagger$ E. Rebours, ${ }^{*} \ddagger$ C. Cebo,${ }^{*}$ and P. Martin ${ }^{\star} \ddagger{ }^{1}$ \\ *INRA, UMR1313 Unité Génétique Animale et Biologie Intégrative, équipe «Lait, Génome \& Santé» F-78350 Jouy-en-Josas, France \\ †Nofima Marin, Muninbakken 9-13, NO-9291 Tromsø, Norway \\ fINRA-Plateforme ICE (Iso Cell Express), F-78350 Jouy-en-Josas, France
}

\begin{abstract}
Mastitis, an inflammation of the mammary gland, is the most costly infectious disease of dairy ruminants worldwide. Although it receives considerable attention, the early steps of the host response remain poorly defined. Here, we report a noninvasive method using milk fat globules (MFG) as a source of mammary RNA to follow the dynamics of the global transcriptional response of mammary epithelial cells (MEC) during the course of a bacterial infection. We first assessed that RNA isolated from MFG were representative of MEC RNA; we then evaluated whether MFG RNA could be used to monitor the MEC response to infection. Sufficiently high yields of good-quality RNA (RNA integrity numbers ranging between 6.7 and 8.7) were obtained from goat MFG for subsequent analyses. Contamination of MFG by macrophages and neutrophils, which can be trapped during creaming, was assessed and when using quantitative real-time PCR for cell-type specific markers, was shown to be weak enough $(<8 \%)$ to affect MFG gene expression profiling. Using microarrays, we showed that RNA extracted from MFG and from mammary alveolar parenchyma shared approximately $90 \%$ of the highlighted probes corresponding in particular to genes encoding milk proteins ( $C S N, B L G, L A L B A)$ and enzymes involved in milk fat synthesis and secretion (FASN, XDH, ADRP, SCD, and DGAT1). In addition, a gene involved in the acute-phase reaction, coding for the serum amyloid A3 (SAA3) protein, was found within the first 50 most highly expressed genes in a noninfectious context in both mammary alveolar parenchyma and MFG, strongly suggesting that SAA3 is expressed in MEC. We took advantage of this noninvasive RNA sampling to follow the early proinflammatory response of MEC during the course of a bacterial infection and showed that the levels of mRNA encoding
\end{abstract}

Received April 6, 2012.

Accepted May 22, 2012

${ }^{1}$ Corresponding author: patrice.martin@jouy.inra.fr
SAA3 sharply increased at $24 \mathrm{~h}$ postinfection. Taken together, our results demonstrate that MFG represent a unique source of MEC RNA to noninvasively sample sufficient amounts of high-quality RNA to assess the dynamics of MEC gene expression in vivo, especially during the first steps of infection, thereby paving the way for the discovery of early biomarkers for the control of intramammary infections. Furthermore, this noninvasive technique could be used to provide mammary transcriptomic data on a large scale, thus filling the gap between genomic and phenotypic data.

Key words: gene expression profiling, milk fat globule, mastitis, serum amyloid A3

\section{INTRODUCTION}

Mastitis, which is an inflammation of the mammary gland (MG) commonly caused by bacterial infection, is the most costly infectious disease of dairy ruminants worldwide because of the reduced milk yield, milk discarded after treatment, and cost of veterinary services (Sordillo and Streicher, 2002). Although mastitis receives considerable attention, the early steps of the host response remain poorly defined and understood. Indeed, it is challenging to obtain genetic material from the MG. Usually, surgical sampling techniques from mammary biopsies or from tissue samples taken at slaughter provide large amounts of tissue (Farr et al., 1996; Schmitz et al., 2004). Unfortunately, multiple postinvasive complications can arise, and because of the great heterogeneity of the mammary tissue, these samples may not be representative of the milk-synthesizing tissue and mammary biology. In addition, they do not provide opportunities for multiple sampling, to perform longitudinal studies and follow-up on local epithelial changes at the early stages of infection. An alternative is to use endoscopic techniques for the collection of fresh MG biopsies (Vangroenweghe et al., 2006; VanKlompenberg et al., 2012). However, with such techniques, it is difficult to collect biopsy samples from the alveolar tissue in the upper part of the MG 
rich in secretory parenchyma. Therefore, noninvasive techniques using milk components could overcome such limitations.

Milk contains somatic cells, a heterogeneous population of cells including epithelial cells exfoliated from the mammary epithelium. Indeed, during lactation, mammary epithelial cells (MEC) are normally subject to an important turnover and are continually replaced by new cells (Capuco et al., 2001). These exfoliated cells are discharged into the milk and form a small part of milk somatic cells. Using RNA extracted from this part of somatic cells could be a significant improvement in assessing the gene activity of the mammary secretory epithelium and could allow easy and repetitive sampling without damaging mammary tissue (Boutinaud and Jammes, 2002; Boutinaud et al., 2002). Nevertheless, most of the epithelial cells present in milk are dead cells that have reached the end of their secretory life. Consequently, the information contained in such cells probably does not reflect the true metabolic situation of MEC (Krappmann et al., 2012).

Another alternative was proposed by Maningat et al. (2007, 2009), who reported the use of milk fat globules (MFG) as a source of mammary RNA in humans. Indeed, cytoplasmic crescents can be included in MFG, as first described by Wooding et al. (1970) in the goat and human. This mode of secretion with the loss of secretory cell material was considered specific to fat and is termed the apocrine mechanism. In fact, cytoplasmic lipid droplets, first originating from the endoplasmic reticulum, bulge against and gradually become enveloped in the apical plasma membrane, finally pinching off from the cell as MFG (McManaman et al., 2007). Intracellular components (membranes and organelles) of MEC become trapped within the MFG, which therefore contain cytoplasmic material other than the nucleus (Huston and Patton, 1990; Heid and Keenan, 2005). In addition, this apocrine secretion process is not exclusive to humans and goats. Crescents of cytoplasmic material have been observed in several species, such as the cow, rat, pig, sheep, and rabbit (Wooding, 1971; Janssen and Walstra, 1982). Taking advantage of this feature, Maningat et al. (2009) claimed that MFG represent potential material from which it is easy to obtain repeated samples of the cytoplasm of MEC. However, given the difficulty of sampling healthy mammary tissue from the human breast, no demonstration existed that RNA extracted from MFG were really representative of the genome expressed in MEC.

In this study, we used the RNA sampling method proposed by Maningat et al. (2007) for the goat species, with the aim of checking whether RNA exported by MFG, given the fat secretion process, come exclusively from MEC and reflect its transcriptional activity. To address this issue, we compared gene expression patterns of the mammary alveolar parenchyma (MAP), which are essentially composed of MEC, and of MFG isolated from milk of the same goat by using microarray technology. In addition, quantitative real-time PCR (qPCR), which is characterized by a wide dynamic quantification range, was used to determine the expression of some specific genes. We report here that such a noninvasive RNA sampling procedure provides a unique opportunity to obtain a sufficient amount of good-quality RNA. We also demonstrate that this material, which showed a good correlation with the gene expression profile of MAP, is representative of the MEC transcriptome in the goat species. Furthermore, we successfully applied this approach to follow the response of MEC early in the infection process of the goat MG by using the acute-phase serum amyloid A3 protein (SAA3), which is known to be a specific marker of inflammation.

\section{MATERIALS AND METHODS}

\section{Overall Strategy}

The first part of the study, which was dedicated to comparing MFG RNA with MAP RNA, was performed in a noninfected context, starting from materials (milk fat and mammary tissue) collected from the same goat, by using both microarray and qPCR. The objective was to demonstrate that the MFG transcriptome reflects the MEC transcriptome. The second part, designed to validate the noninvasive RNA sampling protocol using MFG, was conducted on 8 goats to assess this sampling procedure and thereby to demonstrate by using qPCR that MFG-extracted material is useful in monitoring the MEC response to an infectious challenge by Staphylococcus aureus.

\section{Animals and Milk Samples}

Eight Alpine goats, at the early peak of lactation (30 to 40 DIM), at first parity and without IMI, were chosen and housed at the Centro Zootecnico Didattico Sperimentale of the Facolta of Medicina Veterinaria (Universita di Milano, Milan, Italy). Milk samples from the 8 healthy goats were collected by hand into sterile, RNase-free tubes $(3 \times 50-\mathrm{mL}$ Falcon tubes $)$, taking care to avoid any RNase contamination. The samples were immediately placed on ice before MFG collection.

Before intramammary challenge, both half-udders were milked by hand and emptied, and the teat ends were carefully disinfected with chlorhexidine. The left half-udder of each goat was infused with $1 \mathrm{~mL}\left(10^{3}\right.$ $\mathrm{cfu} / \mathrm{mL}$ ) of inoculum of Staph. aureus strain DV137. 
The right half-udder, used as a noninfected control, was infused with $1 \mathrm{~mL}$ of sterile pyrogen-free PBS. Subsequent milk sample collections were carried out at $6,12,18,24$, and $30 \mathrm{~h}$ postchallenge from both the right (uninfected) and left (infected) half-udder, taking care to prevent RNase contamination. At each time point, $150 \mathrm{~mL}$ of milk samples were collected for each half-udder of the 8 goats and transferred into sterile RNase-free tubes $(3 \times 50$-mL Falcon tubes $)$. Samples were immediately kept on ice before MFG preparation.

\section{MFG Collection}

Samples were centrifuged at $2,000 \times g$ for $10 \mathrm{~min}$ at $4^{\circ} \mathrm{C}$ to isolate milk fat. The supernatant fat layer was then transferred to a new 50-mL Falcon tube by using a sterile spatula. A $500-\mu \mathrm{L}$ quantity of fat was then put into a $15-\mathrm{mL}$ Falcon tube, and $1.5 \mathrm{~mL}$ of TRIzol LS solution (Invitrogen Life Technologies Inc., Carlsbad, CA) was added and the mix was vortexed vigorously before storage at $-80^{\circ} \mathrm{C}$. The entire process of milk sample collection and storage of MFG was completed within $2 \mathrm{~h}$, and all procedures were carried out at $4^{\circ} \mathrm{C}$.

\section{MAP Collection}

Goats were slaughtered at $30 \mathrm{~h}$ postinfection according to surgical and experimental procedures in compliance with the policy of the INRA Animal Care Committee after milk sampling. Tissue samples were collected aseptically from goats within $10 \mathrm{~min}$ after slaughter. A piece of deep alveolar parenchyma, without visible connective tissue, was removed from the left udder (infected) and right udder (noninfected), rapidly frozen in isopentane chilled over liquid nitrogen, and stored as original material at $-80^{\circ} \mathrm{C}$ for further analyses.

\section{Total RNA Isolation and Assessment of RNA Integrity}

Total RNA was extracted from MFG and MAP by using a TRIzol LS solution (Invitrogen Life Technologies Inc.) following the original manufacturer's protocol, with slight modifications. Briefly, frozen samples $(500 \mu \mathrm{L}$ of milk fat $+1.5 \mathrm{~mL}$ of TRIzol LS) were placed at room temperature for $30 \mathrm{~min}$ or until thawing. A first centrifugation at $12,000 \times g$ was performed for 10 min at $4^{\circ} \mathrm{C}$ to remove lipids. A $400-\mu \mathrm{L}$ quantity of chloroform was then added to the remaining solution and the mix was shaken vigorously. After centrifugation, the upper aqueous layer (approximately 60\%), which contained RNA, was carefully pipetted, and RNA was precipitated by adding $750 \mu \mathrm{L}$ of isopropanol/1 $\mathrm{mL}$ of TRIzol LS used for extraction. After centrifugation $\left(12,000 \times g\right.$ for $10 \mathrm{~min}$ at $\left.4^{\circ} \mathrm{C}\right)$, RNA pellets were washed with $75 \%$ ethanol, dissolved in $30 \mu \mathrm{L}$ of RNase-free water, and finally stored at $-80^{\circ} \mathrm{C}$ until further processing. Before RNA quality control, a DNase treatment was carried out to remove any contaminating genomic DNA according to the manufacturer's protocol (Qiagen, Hilden, Germany).

\section{RNA Quality Control and Single-Strand cDNA Synthesis}

The purity, concentration, and integrity of total RNA intended for microarray analysis and qPCR were assessed using 2 independent techniques. Purity of the RNA was evaluated by absorbance (A) readings (ratio of A260/A230 and A260/A280) using a NanoDrop ND-1000 spectrophotometer (Thermo Fisher Scientific, Waltham, MA). The fluorometric method and microcapillary electrophoresis device developed by Agilent Technologies (Palo Alto, CA) was used to determine RNA concentration and quality with an RNA 6000 Pico LabChip Kit in an Agilent Bioanalyzer 2100 system (Agilent Technologies). Quality was evaluated using the RNA integrity number value introduced by Schroeder et al. (2006). First-strand cDNA was synthesized from 5 to $10 \mathrm{ng}$ of total RNA primed with oligo(dT) $)_{20}$ and random primers $(3: 1, \mathrm{vol} / \mathrm{vol})$ using Superscript III reverse transcriptase (Invitrogen Life Technologies Inc., Carlsbad, CA) according to the manufacturer's instructions. One microliter of $2 \mathrm{U} / \mu \mathrm{L}$ RNase $\mathrm{H}$ (Invitrogen Life Technologies) was then added and the reaction mix was incubated for $20 \mathrm{~min}$ at $37^{\circ} \mathrm{C}$ to remove RNA from the heteroduplexes. The single-strand cDNA thus obtained was stored at $-20^{\circ} \mathrm{C}$.

\section{Microarray Processing and Data Analysis}

Usually, this sensitive method is used to compare similar material. Because our purpose was to compare 2 materials from different origins (RNA from a heterogeneous tissue made up of different cell types vs. RNA from MFG, presumably arising from a unique cell type, MEC), we chose to perform technical replicates from 1 uninfected goat to overcome the individual variability and to test the repeatability of the method. Ribonucleic acid samples were labeled using T7 RNA polymerase, which simultaneously amplifies target material and incorporates cyanine 3 (Cy3)- or cyanine 5 (Cy5)-labeled cytidine triphosphate (Agilent Technologies), according to the manufacturer's instructions. Briefly, total RNA (120 ng) was first reverse transcribed and then converted to labeled cRNA with $\mathrm{Cy} 3$ or $\mathrm{Cy} 5$ dyes. Before hybridization, the quantity and quality of purified cRNA was assessed with an Agilent 2100 Bioanalyzer (Agilent Technologies). Given that goat microarrays were not 
available, we used a microarray developed for a closely related species (Ovis aries) to profile gene expression. The microarray used in this study was a Sheep Gene Expression Microarray, $8 \times 15 \mathrm{~K}$ (Agilent Technologies). The hybridization was performed according to the manufacturer's instructions. Briefly, each microarray was cohybridized with 2 fluorescent-labeled (Cy3 and Cy5) cRNA samples. Three hundred nanograms of each labeled cRNA was fragmented for $30 \mathrm{~min}$ at $60^{\circ} \mathrm{C}$ in $25 \times$ fragmentation buffer. The fragmented and labeled cRNA samples were then diluted in $2 \times$ GEx Hybridization Buffer Hi-RPM (Agilent Technologies) and hybridized on the $15 \mathrm{~K}$ ovine microarray for $17 \mathrm{~h}$ at $60^{\circ} \mathrm{C}$ in a rotating hybridization oven. After hybridization, microarrays were washed twice with Wash Buffer 1 (Agilent Technologies) at room temperature for $1 \mathrm{~min}$ and then with Wash Buffer 2 (Agilent Technologies) at $37^{\circ} \mathrm{C}$ for $1 \mathrm{~min}$. Microarrays were scanned on an Agilent G2565BA scanner (Agilent Technologies) using the extended dynamic range scan mode. Data were processed (including Lowess normalization) and extracted with Feature Extraction software, version 10.5 (Agilent Technologies). This software quantified mean and median signals for each sample and for background estimation according to the GE2_NonAgilent_91 extraction protocol. Extracted data were analyzed using a qualitative method to determine which genes were expressed, considering the false positives. In this process, we used an intensity-based analysis, in which the mean intensity of the dye-normalized intensities in the 2 channels were kept separate, instead of a ratiobased analysis, considering that 1 cohybridized target does not influence the hybridization of the other ('t Hoen et al., 2004). Indeed, the distribution of mean signal intensity of each cyanine was similar from a $\log _{2}$ (Lowess-normalized mean signal) $>5$. Therefore, the intensity of each spot (for both the $\mathrm{Cy} 3$ and the $\mathrm{Cy} 5$ channels) was initially filtered for good quality, based on the default parameters provided by the Feature Extraction Software using R statistical software (http:// www.r-project.org/). Briefly, a spot was defined as good if it was not flagged as a saturation and nonuniformity outlier and was considered as beingfound according to the local background and the spot diameter (Agilent Feature Extraction Software version 10.5 User Guide, Agilent Technologies)] in a single channel. A gene was defined as present if it was represented by a good spot in both the $\mathrm{Cy} 3$ and $\mathrm{Cy} 5$ channels, and the mean intensity signal was positive and significantly above background according to a 2 -sided $t$-test $(P=0.01)$ and was not in the negative control range. Otherwise, a gene was considered absent. Probes considered present for each material, MAP and MFG, were then compared using a Venn diagram to obtain a common list between MFG and MAP and a specific list for MFG and for MAP. Each set of genes was referenced to biological functions with Ingenuity Pathway Analysis software version 6.0 (IPA; Ingenuity Systems, Redwood City, CA). The contribution of genes to the identified function was explained with an associated $P$-value, calculated with a right-tailed Fisher exact test.

\section{Primer Design and $q P C R$}

The RNA isolated from MFG was used to determine, for each goat, the expression of selected genes of interest by qPCR, as described by Bevilacqua et al. (2006), by using a SYBR Green PCR Master Mix and an ABI Prism 7900 Sequence Detection System (Applied Biosystems, Life Technologies, Carlsbad, CA). The primers used were described previously (Bevilacqua et al., 2006) except for CD15 (Hisano et al., 2001), CD18, GPR97 (Robbins et al., 2008; Crozat et al., 2010), MPO, and M-SAA3 (this study). The Bovine Genome Database (http://BovineGenome.org) was queried for reference mRNA sequences. Expressed sequence tags of caprine sequences found by a nucleotide Basic Local Alignment Search Tool search and reference were aligned to create consensus. Only exon-exon junctions, with great homology between sequences, were chosen for primer design with Primer Express Software version 2.0 (Applied Biosystems, Life Technologies) and were purchased from MWG Biotech (Ebersberg Germany; Table 1).

To estimate the representativeness of MFG as a starting material to analyze gene expression in MEC, 3 MEC-specific markers, namely, CSN2, CSN3, and $L A L B A$ transcripts, were quantified after normalization by 2 internal control genes, S24 ribosomal protein (RPS24) and cyclophylin (PPIA), which were validated by the GeNorm Visual Basic application (Microsoft Corp. Redmond, WA). Furthermore, qPCR systems were designed to quantify specific markers for mammary myoepithelial cells (Krt14), lymphocytes (CD3e), neutrophils (MPO, CD15, GPR97, and CD18), and macrophages (CD68 and $C D 18)$. We also quantified transcripts from fatty acid synthase $(F A S N)$, which is expressed in several mammary cell types, including MEC and adipocytes.

Primer efficiency was first validated with a standard curve of 4 serial dilution points (ranging between 1 $\mathrm{ng}$ and $1 \mathrm{pg}$ of reverse-transcribed total RNA) and a no-template control. Regarding the specificity of neutrophil markers, we validated primers using a standard curve of RNA extracted from a polymorphonuclear neutrophil (PMN) population isolated from the blood of a healthy goat. The qPCR amplification mixture $(20$ $\mu \mathrm{L}$ ) contained $5 \mu \mathrm{L}$ of single-strand cDNA template, 
Table 1. Primers used for quantitative real-time PCR analysis and sizes of amplicons ${ }^{1}$

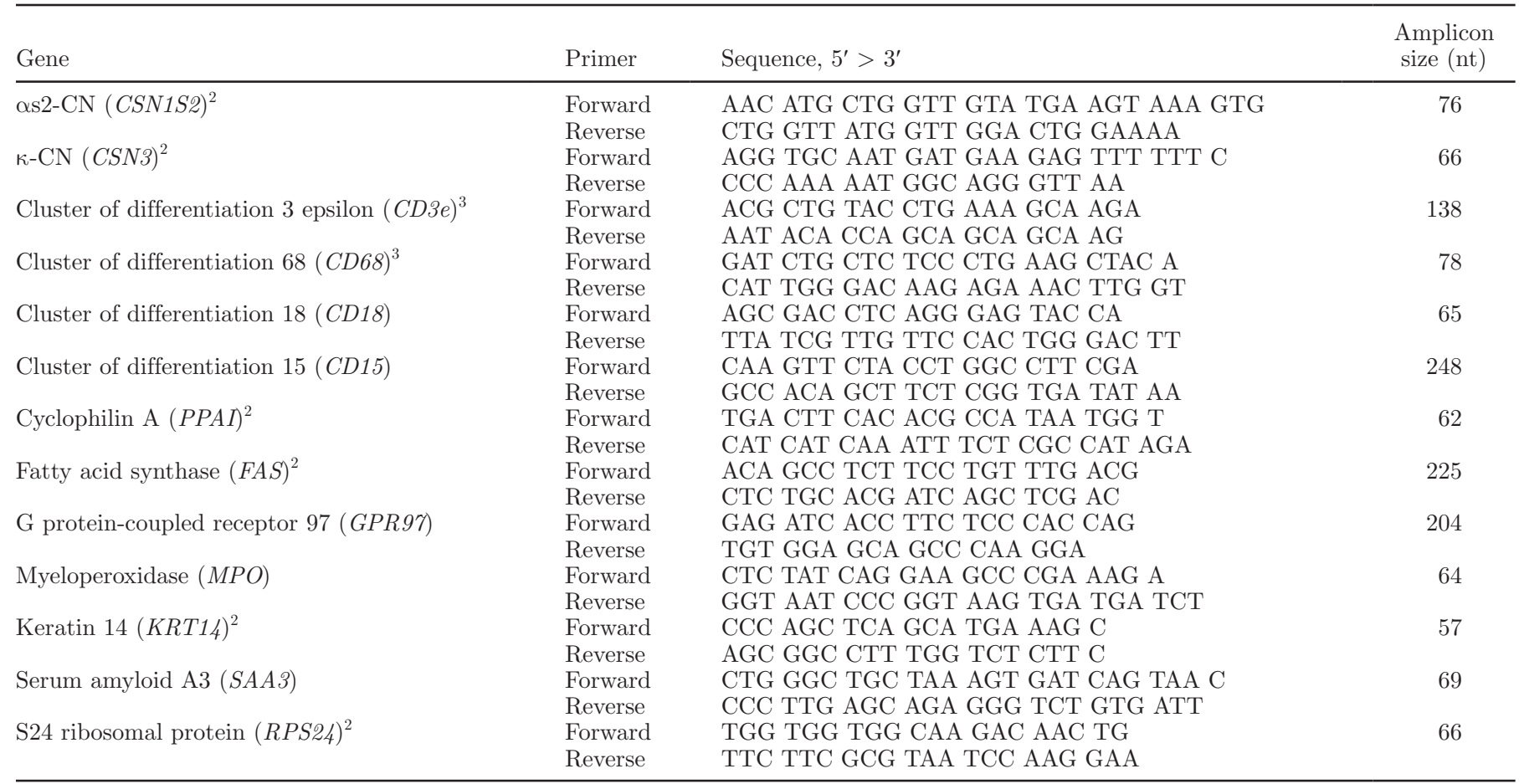

${ }^{1}$ Each pair of primers amplifies the target cDNA [amplicon sizes ranging between 57 and 248 nucleotides (nt)] in its 3' untranslated region. Primer pairs were designed with Primer Express Software version 2.0 (Applied Biosystems, Foster City, CA) except for S24 ribosomal protein primers, which were manually designed.

${ }^{2}$ Primer pairs were from Bevilacqua et al. (2006).

${ }^{3}$ Primer pairs were from Bevilacqua et al. (2010).

$10 \mu \mathrm{L}$ of $2 \times$ Power SYBR Green PCR Master Mix buffer (Applied Biosystems, Life Technologies), and 1.2 $\mu \mathrm{L}$ of forward and reverse primers $(5 \mu M)$ to reach a final primer concentration of $300 \mathrm{n} M$. After optimization of the qPCR systems (efficiency ranging between -3.30 and -3.45 ), amplification reactions were run (in triplicate). The results generated by the Sequence Detection Software (version 2.3; Applied Biosystems, Life Technologies) were exported as tab-delimited text files and imported into Excel (Microsoft Corp.) for further analyses. Relative quantification analysis was performed using the free software program qBase (Hellemans et al., 2007), in which relative expression levels were normalized with respect to the selected housekeeping genes (RPS24 and PPIA), following the MIQE (minimum information for publication of qPCR experiments) guidelines (Bustin et al., 2009).

\section{Statistical Analysis}

The reliability of reference genes (RPS24 and PPIA) was evaluated with the GeNorm Visual Basic application for Excel (Microsoft Corp.) as described by Vandesompele et al. (2002). All the statistical analy- ses were performed with the Rcmdr package (http:// cran.r-project.org/web/packages/Rcmdr/index.html), using $\mathrm{R}$ software. A nonparametric Mann-Whitney $U$-test was used to analyze the differences in relative expression of target genes between MFG and MAP.

\section{RESULTS AND DISCUSSION}

As an alternative to the commonly used techniques of sampling RNA from MEC (biopsies or somatic cells), we evaluated the use of material isolated from MFG, as first proposed for humans by Maningat et al. (2007). Such an approach could, in fact, be a convenient strategy to access the genome expressed by MEC noninvasively, provided that MFG RNA proved to be representative of the MEC transcriptome. Therefore, our first objective in this study was to demonstrate that this RNA comes essentially, if not exclusively, from MEC, which are by far the main cell type represented in the MAP. The second part of this study was designed as a validation test, to show that MFG-extracted material is pertinent for following the MEC response accurately during the time course of an experimental infection. 


\section{MFG, a Unique Source of RNA from MEC}

Total RNA Isolation and Assessment of Quantity and Quality. Ribonucleic acids from MFG and MAP were isolated according to the complete workflow given in Figure 1. Quantities of total RNA extracted from the MFG and MAP of goats $(\mathrm{n}=8)$ were $78 \pm$ $20 \mathrm{ng} / \mathrm{mg}$ of cream layer $(2.5 \mathrm{~mL}$ of milk) and $1.2 \pm$ $0.5 \mu \mathrm{g} / \mathrm{mg}$ of mammary tissue, respectively. Total RNA were then assessed for their purity and shown to be free of protein contamination, with absorbance ratio (A260/A280) values ranging between 1.94 and 2.11. In addition, the integrity of RNA was assessed using the Agilent 2100 Bioanalyzer (Agilent Technologies), which calculates RNA integrity number values ranging between 6.7 and 8.7. These results underline the fact that RNA extracted from MFG was of comparable quality with RNA obtained from MAP.

Potential Contamination by Immune Cells Present in Milk. Before MFG and MAP transcriptomes were compared by microarray and qPCR, it was crucial to evaluate the possible contamination of RNA from MFG by RNA from macrophages and PMN, which are the main leukocyte cell types in milk from healthy goat udders: $63.0 \%$ PMN, $16.2 \%$ macrophages, $7.2 \%$ lymphocytes, and $13.0 \%$ remaining cells (Rota et al., 1993). In addition, these immune cells are well known to have a strong affinity for the MFG, directed toward cell membranes. Therefore, they can be trapped in the cream layer during the centrifugal preparation of MFG (Lee et al., 1980; Sarikaya, 2006), and RNA extracted from MFG can be contaminated by RNA from macrophages or PMN. To evaluate the level of RNA contamination, $\mathrm{qPCR}$ analysis was carried out by using specific markers of immune cells reported in the literature: $C D 68$ for macrophages and $C D 3 e$ for lymphocytes (Hisano et al., 2001). Concerning PMN markers, expression levels of 4 genes (MPO, CD15, GPR 97, and CD18) were tested on RNA extracted from a PMN population isolated from goat blood, with a standard curve diluted in 10-fold increments to cover a quantitative range of 4 magnitudes (1,000 to $1 \mathrm{pg})$. Only 2 markers (CD18 and GPR97) were accepted, given their calculated efficiency (95\%) and their expression levels. A marker for mammary myoepithelial cells (Krt14) was also searched as a negative control. The results showed that Krt14 and $C D 3 e$ messengers were absent from the MFG, and markers for macrophages and PMN (CD68, CD18 and GPR ${ }^{7}$ ) were present at very low amounts relative to MAP (Figure 2). These weak values for $C D 68$ [relative quantity (RQ) mean $C D 68=0.11], G P R 97$ (RQ mean GPR97 =0.07), and $C D 18(\mathrm{RQ}$ mean $C D 18=0.18)$ reflect a slight but nonsignificant contamination by the corresponding immune cells during MFG preparation.
This contamination remained 20-fold lower, as compared with MAP. Therefore, our results demonstrate that we obtained a sufficient amount of good-quality RNA from MFG, which was slightly contaminated by immune cells, starting from milk collected from a healthy udder.

Does the MFG Transcriptome Reflect the MAP Transcriptome? To delve further into the description of RNA obtained from MFG, we used microarray technology to create a global picture of the genome-wide profile of MFG. We chose to compare the set of genes present in MFG with the set of genes present in MAP, an easy-to-sample material composed of more than 90\% MEC (Faucon et al., 2009). Among the 15,208 probe sets analyzed on the Sheep Gene Expression Microarray, 9,152 probes in MAP and 9,645 probes in MFG had a mean signal significantly greater than that of the background $(P<0.01)$. These results highlighted genes for which messengers were considered present in MAP and MFG, respectively. Given the cell composition of MAP, one would expect to see more genes present in MAP than in MFG. This unexpected result was, in fact, due to default parameters calculated by the Feature Extraction software, which flagged a higher number of hits in MAP, reducing the noise generated by this tissue. These 2 sets of probes corresponded to 8,789 genes in MAP and 9,241 genes in MFG, with 8,220 genes in common between MFG and MAP. In other words, MFG and MAP expression profiles shared between 89 and $93.5 \%$ of the genes highlighted (Figure 3), with a good gene expression correlation for all genes commonly expressed in MFG and MAP (Figure 4). Within this large set in common, we found, as previously reported in both mice and humans (Rudolph et al., 2003; Maningat et al., 2009), the most highly expressed mammary genes, which were mainly those encoding milk proteins ( $L A L B A, C S N$, and $B L G$ ) and those involved in protein synthesis $(R P L$ and $R P S$; Table 2). It was surprising that FTH1 (ferritin heavy polypeptide 1), the major intracellular iron-storage protein, was found within this set of highly expressed genes. The overexpression of FTH1 is associated with a reduction in cellular labile iron, oxidative stress, and inhibition of apoptosis (Epsztejn et al., 1999; Berberat et al., 2003). Lee et al. (1996), however, observed that ferritin heavy chain was highly expressed during involution of the mouse MG. Perturbations in its expression levels have been reported as being associated with the progression of breast cancer (Shpyleva et al., 2011). Among these common genes, we found highly expressed genes involved in fatty acid and triglyceride synthesis and secretion (FASN, XDH, ADRP, SCD, and DGAT1) but also genes involved in lactose synthesis, such as uridine diphosphate-galactosyltransferase (B4GALT1). 

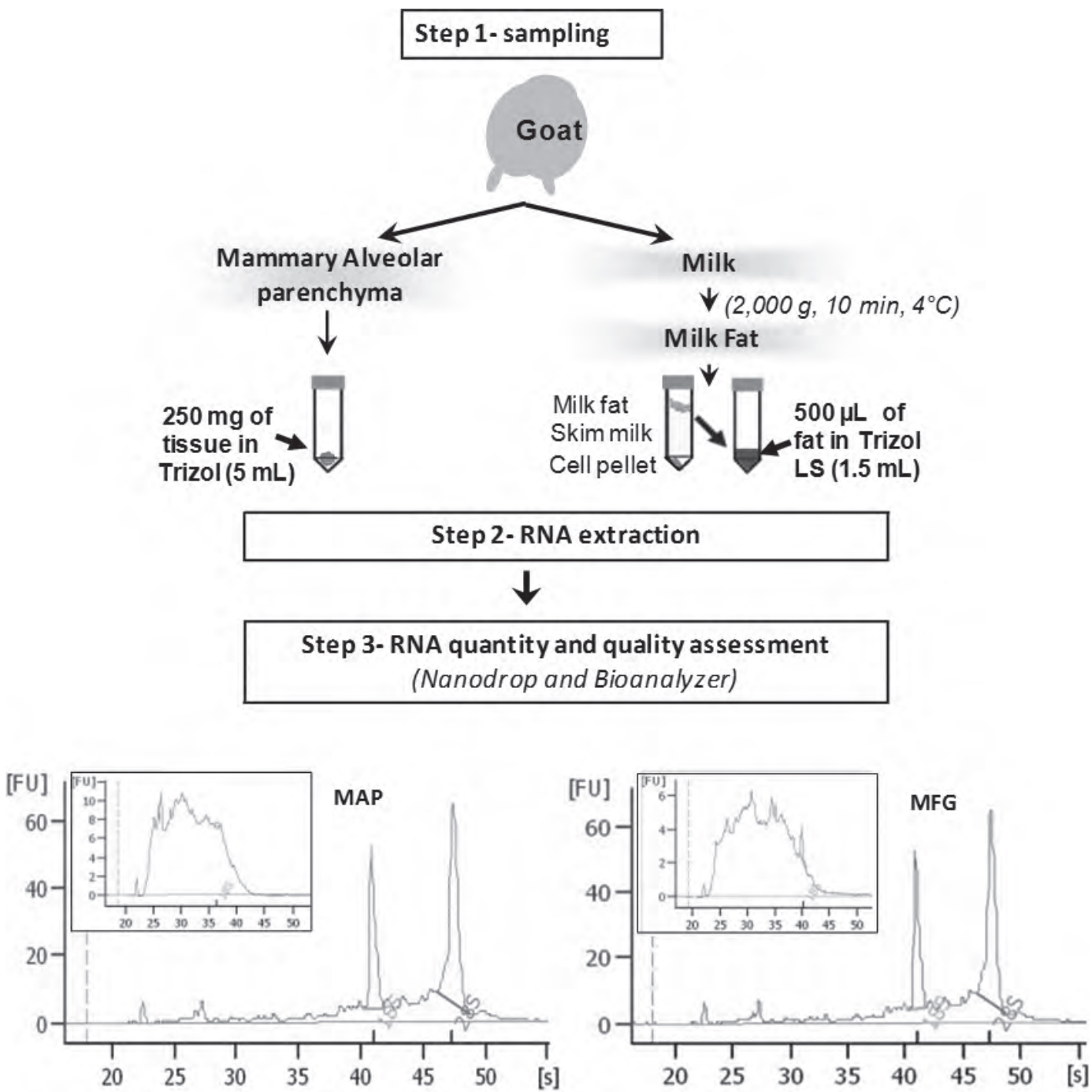

$\mathrm{RIN}=8.1 \pm 0.6$

Yield $=1.2 \pm 0.5 \mu \mathrm{g} / \mathrm{mg}$ of tissue

$\mathrm{RIN}=7.7 \pm 0.9$

Yield $=\mathbf{7 8} \pm 20 \mathrm{ng} / \mathrm{mg}$ of cream layer

Figure 1. Ribonucleic acid extraction workflow, including RNA yield and quality assessment. The workflow was composed of 3 steps. First, milk was skimmed by centrifugation, the milk fat was rapidly put in TRIzol LS solution (Invitrogen Life Technologies Inc., Carlsbad, CA), and the mammary alveolar parenchyma (MAP) were collected from the slaughtered animal (step 1). Next, RNA was extracted from MAP and from milk fat globules (MFG) of the same goat according to the manufacturer's recommendations (step 2). Finally, the quantity and quality of each sample was assessed using both a Nanodrop spectrophotometer (Thermo Fisher Scientific, Waltham, MA) and a Bioanalyzer 2100 system (Agilent Technologies, Palo Alto, CA; step 3). Typical examples of Bioanalyzer RNA profiles, showing the 2 peaks of ribosomal RNA (28S and $18 \mathrm{~S}$ ), are given for each type of biological material and for the corresponding cDNA profile (in the box) obtained after reverse transcription. RIN $=$ RNA integrity number; $\mathrm{FU}=$ fluorescence units.

Finally, a comparison of this set with the lactation literature gene set listed by Lemay et al. (2007) showed a similarity of more than $60 \%$, providing further validation of the microarray results (Table 3 ). In addition, to gain a global understanding of the gene list shared between MFG and MAP, we further analyzed data according to the networks and canonical pathways determined by Ingenuity Pathway Analysis software. From this list, 2,982 different genes with known identifiers were mapped to their corresponding gene objects in the Ingenuity Knowledge Base. The most significant canonical pathways obtained were the ubiquitination and PI3K/Akt signaling pathways, which belong to the top canonical pathways also found to be significantly overrepresented in lactating mice (Lemay et al., 2007; Rudolph et al., 2007). Indeed, these signaling pathways play a critical role in controlling the cellular growth and proliferation of MEC (Rossi and Loda, 2003) and 


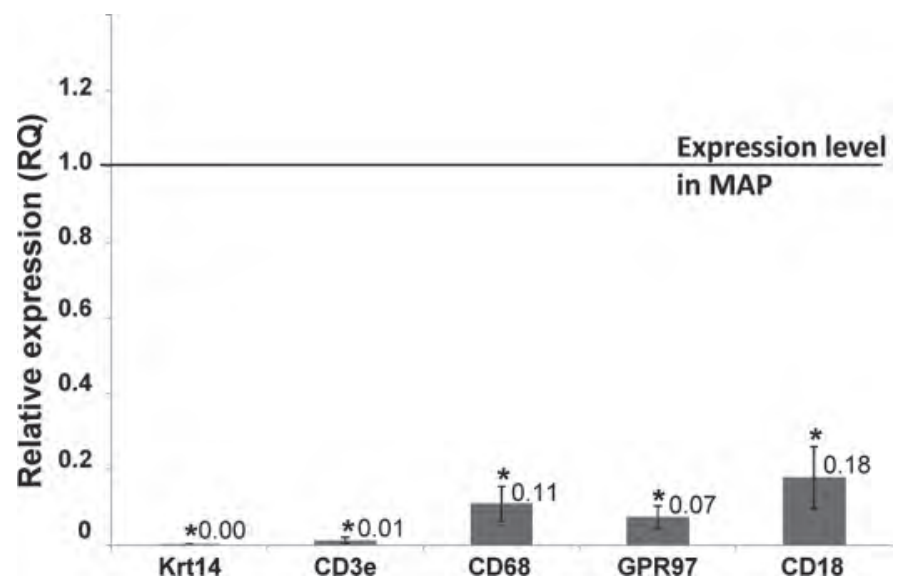

Figure 2. Contamination of milk fat globule (MFG) RNA by immune cell RNA, assessed by quantitative real-time PCR. To estimate the contamination of MFG by immune cells [macrophages, polymorphonuclear neutrophils (PMN), and lymphocytes], mRNA levels of cell-specific markers were assessed by measuring the relative amounts of the relevant genes between MFG and mammary alveolar parenchyma (MAP). Relative quantities (RQ) of specific markers for mammary myoepithelial cells (Krt14), macrophages (CD18 and CD68), lymphocytes (CD3e), and PMN (CD18 and GPR97) were assessed ( $\mathrm{n}=8$ goats) after normalization using PPAI and RPS24. Mean RQ values are given for each gene. A more important signal for $C D 18$ was obtained, consistent with the fact that $C D 18$ targets both macrophages and PMN. Mean RQ \pm SEM are given for each gene. An asterisk $(*)$ indicates ratios are significantly different between MFG and MAP $(P$ $<0.001)$.

in mammary differentiation and synthesis of milk components (Rudolph et al., 2003; Green and Streuli, 2004; Naylor et al., 2005). When such a global compara- tive analysis is used, it appears that MFG and MAP transcriptomes share strong similarities correlating to the lactation function, as would be expected. In this respect, our results are consistent with recent studies carried out using RNA sequencing to perform a comprehensive profiling of genes expressed in cow's milk somatic cells, along the course of lactation (Medrano et al., 2010; Wickramasinghe et al., 2012).

Furthermore, the microarray analysis provides 2 distinct lists with an intensity value lower than $0.1 \%$ of the maximum intensity $(\log <9)$ because of an incomplete superimposition of the MFG and MAP gene lists. The first one consisted of 1,021 genes that were specifically present in MFG, and the second one consisted of 569 genes found only in MAP (Figure 3). This asymmetry could be explained by the fact that even if the whole goat mammary tissue is mainly composed of MEC (Faucon et al., 2009), other cell types, such as mammary myoepithelial cells, adipocytes, and endothelial and immune cells (see the Results section above), are part of this tissue. Thus, as expected, when genes from the MAP specific list were overlaid onto a global molecular network built from information contained in the IPA database, significant cell signaling and metabolic pathways were associated with cell types other than MEC ( $P$-value approximately 5E-03). For instance, analysis emphasized the granzyme B signaling, which characterizes a serine protease, an important granuleassociated enzyme exclusively secreted by cytotoxic $\mathrm{T}$ lymphocytes (Bots and Medema, 2006). Likewise, the

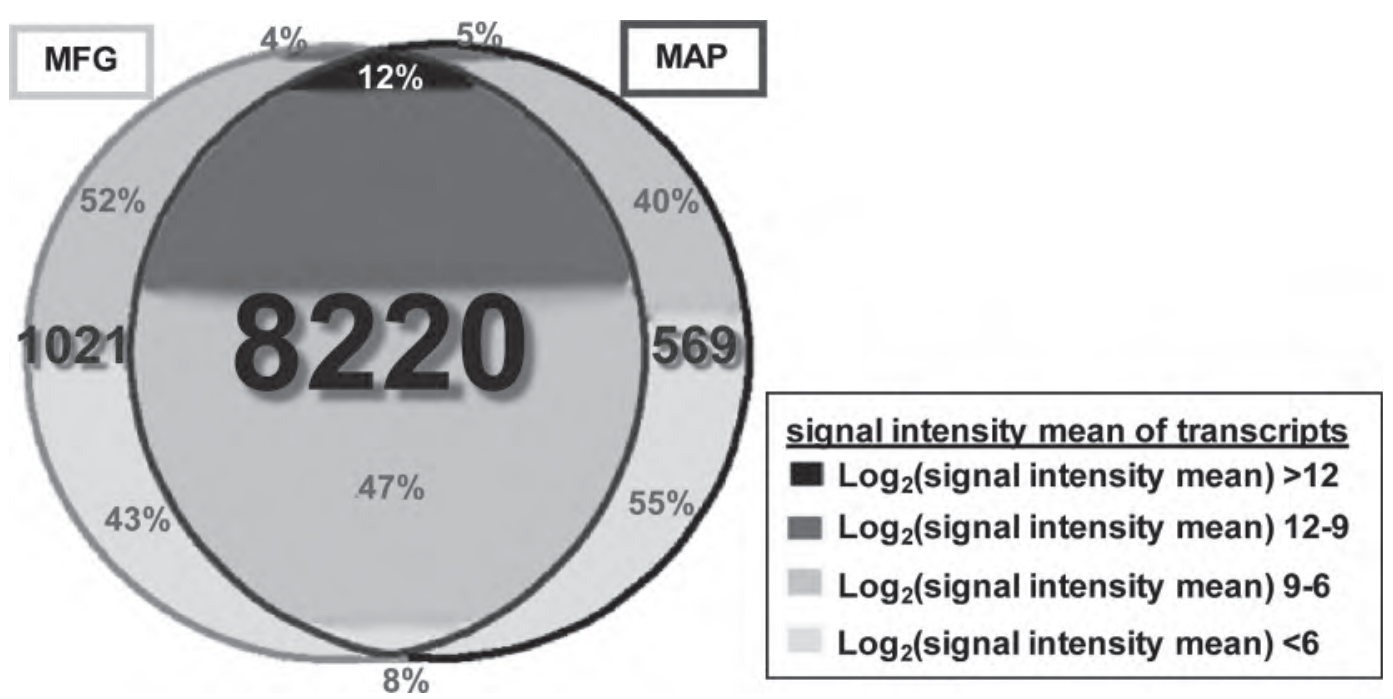

Figure 3. Venn diagram depicting the distribution of transcripts commonly and differentially detected between milk fat globules (MFG) and mammary alveolar parenchyma (MAP). The diagram shows the number of positive probes, which differs significantly between MFG (light gray circle) and MAP (black circle). This diagram also gives the number of probes in common between MFG and MAP (gray area). Each set contains genes expressed significantly above the background by using a $t$-test $(P<0.01)$. Then, in each set, genes are proportionally divided up according to their $\log _{2}$ (signal intensity mean), represented by different levels of gray (4 classes). Percentages correspond to the proportion of transcripts in each $\log _{2}$ (signal intensity mean) class. The Venn diagram was built with VENNY software (Oliveros, 2007). 


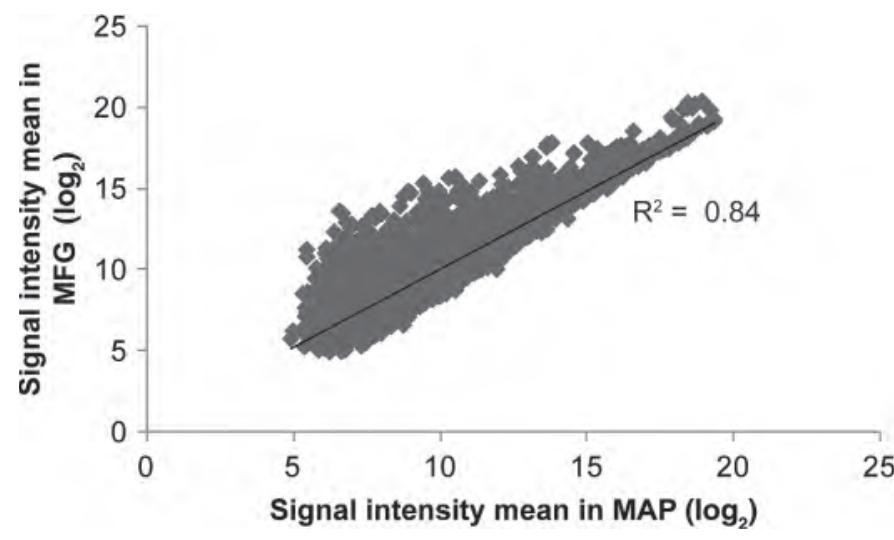

Figure 4. Correlation in gene expression for the 8,220 genes commonly expressed between milk fat globules (MFG) and mammary alveolar parenchyma (MAP).

integrin signaling pathway, known to play an important role in organization of tissue structure and cell adhesion to the extracellular matrix (Schatzmann et al., 2003), was underlined. Consequently, this specific MAP list characterizes the biology of the whole mammary tissue. By contrast, regarding the MFG list, the statistical analysis enabled genes to be highlighted that should be slightly expressed in MEC and were therefore likely diluted among other genes in MAP. These genes were present in MFG, although they were ignored because of the default parameters applied for the whole-tissue analysis. Thus, among the 1,021 genes on this list, 582 with known identifiers were mapped in the Ingenuity Knowledge Base. It is interesting that significant canonical pathway patterns were associated with MEC biology ( $P$-value approximately 2E-04). First, the analysis underlined a marginally significant pathway (LXR/RXR activation). This pathway is composed of proteins involved in lipid metabolism ( $A P O A 1, S C D$, and PTGS2) that are known to be active in MEC and can therefore enter milk via cytoplasmic crescents conveyed by MFG (Lemay et al., 2009). Furthermore, our results indicate that the MFG specific list is significantly associated with a specific cytokine signature of T-helper ( $\mathbf{T h}$ ) cell differentiation. It has been demonstrated that this paradigm also applies to MEC, which undergoes a switch from Th1 to Th2 cytokine production upon the induction of differentiation (Khaled et al., 2007). Consequently, this is compelling evidence that RNA obtained from MFG represent a source of RNA originating in MEC.

To validate the microarray results and accurately assess whether MFG RNA are quantitatively representative of the transcriptional information contained in MEC, we performed qPCR experiments on material isolated from the 8 uninfected goats. Selected genes, known to be expressed specifically in MEC and found in common between MFG and MAP in the microarrays, were analyzed. Relative quantities of specific MEC markers ( $L A L B A, C S N 2$, and CSN3) were assessed after normalization using $P P A I$ and RPS24 as reference genes. Levels of $L A L B A(\mathrm{RQ}$ mean $=0.93)$, CSN2 $(\mathrm{RQ}$ mean $=1.00)$, and CSN3 $(\mathrm{RQ}$ mean $=0.93)$ were significantly unchanged between MFG and MAP, suggesting that these messengers are equally represented in both RNA extracts (Figure 5). Likewise, FASN, a gene expressed in a large panel of tissues (Kusakabe et al., 2000), including cell types with a high lipid metabolism (e.g., adipocytes and hepatocytes, but also MEC), was unchanged $(\mathrm{RQ}$ mean $=0.94)$. Taken together, these results strongly support the notion that the RNA content of MFG reflects the RNA content of MEC.

However, to have precise knowledge of the extent to which the transcriptome of MFG matches the transcriptome of MEC, it would have been necessary to have an MEC reference, such as microdissected cells, and to quantify all genes a priori. To go further in this direction, a study using RNA-seq has been undertaken with the aim of comparing RNA from MAP, microdissected MEC, milk somatic cells, and MFG. Given that this strategy requires the availability of a complete genome, the study was initiated in cattle (manuscript in preparation). This ongoing project will undoubtedly provide a more precise description of the real MEC transcriptome and shed light on the basic issue of what the most relevant material is to profile MEC gene expression during lactation. Nevertheless, this report provides a description of RNA extracted from MFG, and it can be concluded that MFG is a unique source of RNA that satisfactorily reflects the biological status of the MEC in its physiological context. In addition, we showed that this apocrine secretion mode, leading to cytoplasmic crescent formation in MFG, which is not exclusive to humans, makes this noninvasive sampling possible in goats, probably one of the first species in which such an apocrine secretion has been reported (Wooding et al., 1970). It also works in other species, such as mares (Cebo et al., 2012), camels [B. Saadaoui (INRA, UMR1313, Jouy-en-Josas, France), C. Cebo, and P. Martin, unpublished data], and, to a lesser extent, cows (Janssen and Walstra, 1982). Consequently, RNA from MFG is a promising material to easily study MEC functions in several species, which potentiates the use of milk as a biological fluid reflecting the pathophysiological status of mammals. As proof of this concept, we used this material to demonstrate that this approach can be used to follow the MEC response during the course of a bacterial infection in the goat species. 
Table 2. Forty transcripts found in common between milk fat globules (MFG) and mammary alveolar parenchyma (MAP) among the first 50 genes with the highest signal intensity in each set ${ }^{1}$

\begin{tabular}{|c|c|c|c|c|c|}
\hline \multirow[b]{2}{*}{ Encoded protein } & \multirow{2}{*}{$\begin{array}{l}\text { Gene } \\
\text { symbol }\end{array}$} & \multirow[b]{2}{*}{ Probe name } & \multirow{2}{*}{$\begin{array}{l}\text { GenBank } \\
\text { accession no. }\end{array}$} & \multicolumn{2}{|c|}{$\begin{array}{c}\log _{2} \text { (signal } \\
\text { intensity mean) }\end{array}$} \\
\hline & & & & MFG & MAP \\
\hline$\alpha-\mathrm{S} 1-\mathrm{CN}$ & $C S N 1 S 1$ & A_70_P051341 & NM_001009795 & 20.0 & 18.6 \\
\hline$\alpha-\mathrm{S} 2-\mathrm{CN}$ & CSN2S2 & A_70_P030311 & NM_001009363 & 20.0 & 18.4 \\
\hline$\beta-\mathrm{LG}$ & $B L G$ & A_70_P030361 & NM_001009366 & 20.0 & 18.6 \\
\hline $\mathrm{CN} \kappa$ & CSN3 & A_70_P051196 & NM_001009378 & 20.2 & 18.7 \\
\hline Eukaryotic translation elongation factor $1 \alpha 1$ & EEF1A1 & A_70_P024306 & EE832800 & 18.0 & 18.3 \\
\hline Fatty acid synthase & FASN & A_70_P055631 & EE852283 & 19.1 & 19.1 \\
\hline Ferritin, heavy polypeptide 1 & FTH1 & A_70_P039496 & NM_001009786 & 18.4 & 18.2 \\
\hline Glypican 1 & $G P C 1$ & A_70_P027526 & DY509832 & 19.0 & 18.2 \\
\hline Ovis aries translationally controlled 1 & & A_70_P014676 & EU370543 & 18.9 & 19.1 \\
\hline 010914OSAB069080HT Ovis aries cDNA & & A_70_P069091 & EE842470 & 18.9 & 19.1 \\
\hline Ribosomal protein L11 & RPL11 & A_70_P027341 & CF115961 & 17.9 & 17.9 \\
\hline Ribosomal protein L17 & RPL17 & A_70_P018371 & EE779016 & 17.9 & 18.1 \\
\hline Ribosomal protein L19 & RPL19 & A_70_P069131 & EE780718 & 18.4 & 18.4 \\
\hline Ribosomal protein L23a-like & RPL23A & A_70_P001951 & CD288091 & 18.0 & 18.1 \\
\hline Ribosomal protein L27a & $R P L 27 A$ & A_70_P060102 & EE820851 & 18.5 & 18.6 \\
\hline Ribosomal protein L36 & RPL36 & A_70_P001651 & CD289189 & 18.3 & 18.3 \\
\hline Ribosomal protein L37 & RPL37 & A_70_P004951 & EE847110 & 18.6 & 18.6 \\
\hline Ribosomal protein L5 & RPL5 & A_70_P003226 & EE749547 & 18.1 & 18.2 \\
\hline Ribosomal protein L6 & RPL6 & A_70_P014776 & EU366470 & 18.7 & 18.7 \\
\hline Ribosomal protein L7a & $R P L Y a$ & A_70_P068951 & EE814708 & 18.4 & 18.4 \\
\hline Ribosomal protein P1-like & $R P P 1$ & A_70_P012906 & EE843127 & 18.2 & 18.4 \\
\hline Ribosomal protein S10 & RPS10 & A_70_P006086 & EE781464 & 18.6 & 18.7 \\
\hline Ribosomal protein S12 & RPS12 & A_70_P016536 & DQ223559 & 18.7 & 19.0 \\
\hline
\end{tabular}

${ }^{1}$ Fluorescence values are the means of 8 technical replicates from a single goat, and data are presented in alphabetical order (ribosomal genes are given separately).

Table 3. Selected transcripts found in common with the lactation gene set listed by Lemay et al. (2007), specifically in milk fat globules (MFG) and mammary alveolar parenchyma (MAP) or shared between MFG and MAP, and classified according to the different classes of intensity given in the Venn diagram (Figure 3), using the same gray scale

\begin{tabular}{|c|c|c|c|c|}
\hline Gray scale & $\begin{array}{c}\log _{2} \text { (signal } \\
\text { intensity mean) }\end{array}$ & MFG & MFG and MAP & MAP \\
\hline Dark gray & $>12$ & & $\begin{array}{l}\text { LALBA, CSN1S1, } \\
\text { CSN2S2, CSN2, CSN3 }\end{array}$ & \\
\hline Medium-light gray & $9-6$ & $\begin{array}{l}\text { Matrilin, neuregulin 1, IGFBP-3, } \\
\text { cytochrome P450, Ig lambda }\end{array}$ & $\begin{array}{l}\text { Neuropeptide Y, prolactin } \\
\text { receptor, leptin }\end{array}$ & $\begin{array}{l}\text { EIF4A, INSR, POLA2, } \\
\text { AA decarboxylase }\end{array}$ \\
\hline
\end{tabular}




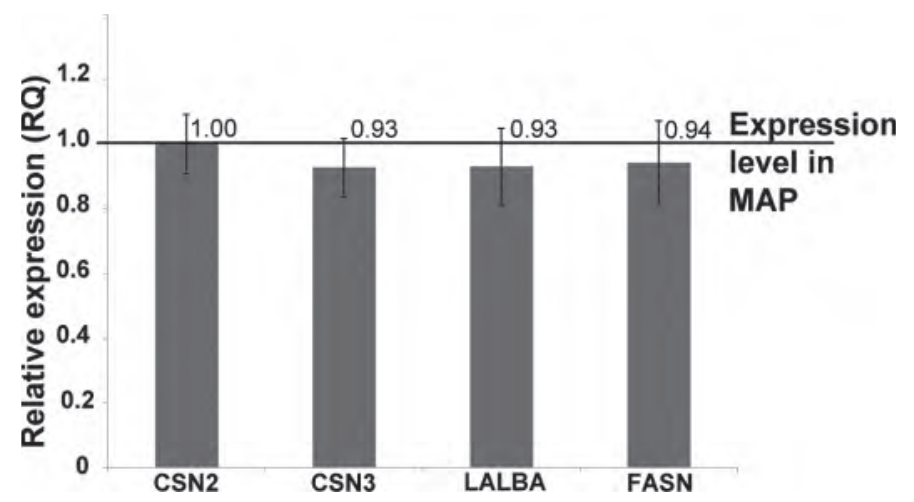

Figure 5. Expression levels of specific markers in milk fat globule (MFG) RNA compared with mammary alveolar parenchymal (MAP) RNA, assessed by quantitative real-time PCR. Messenger RNA levels for cell-specific markers were assessed by measuring the relative expression of the relevant genes between MFG and MAP. Relative quantities of specific markers from mammary epithelial cells (MEC; CSN2, CSN3, LALBA) and a marker of a large panel of cell types, including adipocytes and MEC $(F A S N)$, were assessed after normalization (PPAI and RPS24). Mean relative quantity (RQ) values ( \pm SEM) are given for each gene ( $\mathrm{n}=8$ goats).

\section{MFG: A Promising Tool to Follow the MEC Response in the Early Stages of a Bacterial Infection}

A better understanding of the natural ability of animal resistance could decrease the impact of mastitis causing economical losses and minimize the use of antibiotics. Up to now, different studies on mice (Zheng et al., 2006) and cows (Mitterhuemer et al., 2010; Rinaldi et al., 2010) have focused on the global gene expression of the whole infected mammary tissue. Nevertheless, several lines of evidence indicate a prominent role for MEC in the initiation of the innate immune response (Gray et al., 2005; Strandberg et al., 2005). Several studies have shown that MEC are able to generate a variety of inflammatory mediators, such as cytokines, chemokines, and host defense peptides (Rainard and Riollet, 2006). More recently CXCL3, a cytokine shown to be constitutively expressed by MEC, was identified as the major chemotactic factor for PMN in bovine milk, in the absence of inflammation (Rainard et al., 2008). However, global gene expression patterns of MEC in vivo are lacking because of the limitations in obtaining samples at close intervals during the early stages of mastitis. To assess whether MFG could be a promising tool to follow the MEC response, we studied the expression of the acute-phase protein SAA3 from MFG-extracted material during the course of an experimental infection.

SAA3: A Good Marker to Follow the MEC Response to Infection. Acute-phase proteins are blood proteins primarily synthesized by hepatocytes as a part of the acute-phase response component of the early de- fense. Proteins of the serum amyloid A (SAA) family belong to the acute-phase proteins. They are known to contain several differentially expressed apolipoproteins that can be divided into 2 main classes, acute-phase SAA and constitutive SAA, based on their concentration in plasma under normal conditions or after an acute-phase response (Kushner et al., 1989; Uhlar and Whitehead, 1999). The acute-phase SAA arising from different genes increase in concentration in plasma during the acute-phase response, whereas the constitutive SAA are found associated with high-density lipoprotein under normal conditions but are not significantly increased during the acute-phase response (Whitehead et al., 1992; Steel et al., 1996). Several animal species have been reported to show extrahepatic acute-phase SAA expression and production, particularly in the epithelial cells of several tissues (Urieli-Shoval et al., 1998; Upragarin et al., 2005). Thus, in cows, local production of SAA3, termed M-SAA3 for mammary SAA3, has been hypothesized, likely synthesized by MEC (McDonald et al., 2001; Larson et al., 2005; Weber et al., 2006; Molenaar et al., 2009). This protein has been described as an early specific marker of inflammation (Weber et al., 2006) because its level has been shown to increase dramatically in milk during mastitis (Grönlund et al., 2005; Eckersall et al., 2006). This extrahepatically produced acute-phase protein should play a critical role in protecting the mammary epithelium during mastitis and could be a potential marker to provide information about the inflammatory status of the udder (Weber et al., 2006). Recently, cDNA sequences encoding SAA3 were cloned and sequenced from milk, MG tissue, and the liver in goats (Domènech et al., 2012). We confirmed this expression by the presence of SAA3 messengers in MFG from healthy goats (Table 2). Using MFG RNA sampling, we then followed the evolution of M-SAA3 expression at close and early time points of an experimental infection by Staph. aureus. We observed a significant increase in SAA3 transcripts $(P<0.01)$ between 24 and $30 \mathrm{~h}$ postinfection (Figure 6 ). This sharp increase (2- to 3 -fold) at $24 \mathrm{~h}$ postinfection is consistent with transcriptome analyses on cows (Eckersall et al., 2006; Mitterhuemer et al., 2010), further strengthening the validity of the method. Moreover, on the one hand, we were capable of monitoring the kinetics of SAA3 expression on the same animal, and on the other hand, we were able to use the same animal as a control by using the uninfected half-udder. Consequently, milk sampling appeared as the noninvasive method of choice, to obtain MFG and then RNA easily, to accurately evaluate the expression of genes specifically expressed in MEC during the kinetics of infection. However, given the possible contamination of MFG by immune cells, during the course of infection, we assessed the level of 


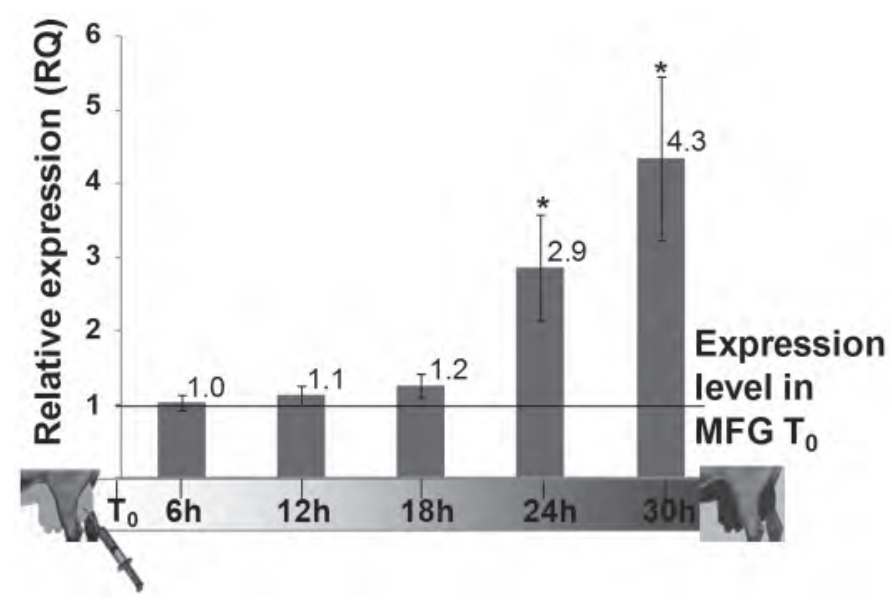

Figure 6. Evolution of the relative expression of serum amyloid A3 (SAA3) in milk fat globules (MFG) during the kinetics of an experimental infection, assessed by quantitative real-time PCR. Milk samples were collected at $6,12,18$, and $24 \mathrm{~h}$ after intramammary injection of Staphylococcus aureus. Data are presented as relative quantity (RQ) mean \pm SEM expression ( $\mathrm{n}=8$ goats). An asterisk $(*)$ indicates a ratio significantly different from MFG at $\mathrm{T}_{0}(P<0.01)$.

contamination of MFG-extracted RNA by using RNA from inflammatory cells.

Possible Contamination of MFG by Immune Cells During Infection. During infection, the composition of milk cells is modified and the possible contamination of MFG by immune cells (macrophages, PMN) could have been a major drawback in performing the kinetic analysis. We showed that, in healthy goats, the contamination was negligible. However, during inflammation, PMN are massively recruited in the udder and they become the principal immune cell types in the mammary tissue and milk (Paape et al., 2000; Sordillo and Streicher, 2002; Zheng et al., 2006). Using qPCR for specific markers of macrophages and PMN (CD18 and CD68), we showed that until $18 \mathrm{~h}$, MFG remained very weakly contaminated by these immune cells $(P>0.1)$. In contrast, at $24 \mathrm{~h}$ postinfection, we observed a significant increase in the expression of specific markers for PMN, but not for macrophages $(P<$ 0.05 ). Is this contamination by neutrophils responsible for the increase in SAA3 messengers observed in MFG? The answer is very likely no because, in a noninfected context, we did not observe any expression of the $S A A 3$ gene $(\mathrm{RQ}$ mean $=0.0004)$ by $\mathrm{PMN}$ isolated from goat blood. Consistent with this observation, Pisoni et al. (2010), who studied the expression profile of goat milk somatic cells, did not find an increase in SAA3 messengers at $24 \mathrm{~h}$ postinfection. In such infectious conditions, PMN account for $96 \%$. Therefore, the gene expression profile recorded is mainly that of neutrophils, strongly suggesting that these immune cells did not express
SAA3 during the Staph. aureus challenge. Likewise, in a pulmonary infection context, the absence of SAA3 expression by neutrophils was observed (Wilson et al., 2005). These results strongly suggest that activated neutrophils exhibit a weak, if any, expression of SAA3, in an inflammation context. Accordingly, one may hypothesize that infiltrating PMN that contaminate MFG from infected goat milk do not contribute to the increase in SAA3 messengers in MFG.

Therefore, taken together, our results demonstrate that the RNA extracted from MFG at the early stages of infection is actually representative of the RNA present in lactating MEC. However, beyond $24 \mathrm{~h}$ postinfection, it is necessary to take into account the presence of PMN and their expression signature. Otherwise, expression analyses could lead to biased results, even though it is well known that the PMN gene expression profile is restricted to a weak number of genes. Indeed, a 3'-directed cDNA library from human peripheral granulocytes (90 to $95 \%$ of PMN) showed an expression profile of 748 different active genes (Itoh et al., 1998). A significant fraction of these genes consisted of nuclear proteins, such as DNA-binding proteins and cytokines, as well as proteins and receptors from the major histocompatibility complex. Nevertheless, it is still possible to adjust gene expression values for changes with cell contamination by applying a computational method for deconvoluting the gene expression profiles (Wang et al., 2006). A more precise reference expression pattern for the milk-activated PMN population, however, remains to be released.

\section{CONCLUSIONS}

To conclude, our results indicate that (1) it is possible to use MFG as a source of RNA representative of MEC RNA for subsequent gene expression studies; and (2) MEC, which form the majority of cells lining the MAP, undoubtedly play a crucial role in the innate immune response to bacterial infections. We succeeded in isolating good-quality RNA from goat milk fat in sufficient amounts to analyze the gene expression patterns of MEC, thus paving the way for a better understanding of functions of this cell type. Furthermore, this noninvasive technique enables genetic materials to be obtained from MEC in vivo, which opens up new avenues for performing longitudinal studies or even largescale analyses, which have been limited and difficult to conceive to date. Thus, mammary transcriptional data that can be considered a kind of "expression typing," filling the gap between genomic and phenotypic data, could be rather easily accessible. Finally, we confirmed the expression of a gene coding for an SAA3 protein in 
the MG and provided strong evidence that this local expression is ensured by MEC and very likely not only during the course of a bacterial IMI.

\section{ACKNOWLEDGMENTS}

We thank Pascal Rainard (INRA, UR1282, Infectiologie et Santé Publique, Nouzilly and Université François Rabelais, UMR 1282, ISP, Tours, France) and Gilles Foucras (INRA, UMR1225 IHAP and Université de Toulouse, INP, ENVT, Toulouse, France) for helpful advice concerning MG immunity and PMN study. We also thank Luc Jouneau (INRA, Molecular Virology and Immunology, Jouy-en-Josas, France) for his excellent expertise in the microarray analysis experiment and Wendy Brand-Williams (INRA, UMR1313 GABI, Jouy-en-Josas, France) for English style editing. We acknowledge colleagues from the experimental farms involved in the care of animals, experimental infection, and tissue sample collection required for this study, especially Leonardo Bianchi and the veterinarian Giuliano Pisoni (Centro Zootecnico Didattico Sperimentale of Facolta of Medicina Veterinaria, Universita di Milano, Milan, Italy). Finally, we thank Rachel Rupp (INRA, UR631, SAGA, Castanet-Tolosan, France), coordinator of the "Capricel" program funded by the Région Centre (Orléans, France).

\section{REFERENCES}

Berberat, P. O., M. Katori, E. Kaczmarek, D. Anselmo, C. Lassman, B. Ke, X. Shen, R. W. Busuttil, K. Yamashita, E. Csizmadia, S. Tyagi, L. E. Otterbein, S. Brouard, E. Tobiasch, F. H. Bach, J. W. Kupiec-Weglinski, and M. P. Soares. 2003. Heavy chain ferritin acts as an antiapoptotic gene that protects livers from ischemia reperfusion injury. FASEB J. 17:1724-1726.

Bevilacqua, C., J. C. Helbling, G. Miranda, and P. Martin. 2006 Translational efficiency of casein transcripts in the mammary tissue of lactating ruminants. Reprod. Nutr. Dev. 46:567-578.

Bevilacqua, C., S. Makhzami, J. C. Helbling, P. Defrenaix, and P. Martin. 2010. Maintaining RNA integrity in a homogeneous population of mammary epithelial cells isolated by Laser Capture Microdissection. BMC Cell Biol. 11:95-108.

Bots, M., and J. P. Medema. 2006. Granzymes at a glance. J. Cell Sci. 119:5011-5014.

Boutinaud, M., and H. Jammes. 2002. Potential uses of milk epithelial cells: A review. Reprod. Nutr. Dev. 42:133-147.

Boutinaud, M., H. Rulquin, D. H. Keisler, J. Djiane, and H. Jammes. 2002. Use of somatic cells from goat milk for dynamic studies of gene expression in the mammary gland. J. Anim. Sci. 80:12581269.

Bustin, S. A., V. Benes, J. A. Garson, J. Hellemans, J. Huggett, M. Kubista, R. Mueller, T. Nolan, M. W. Pfaffl, G. l. Shipley, J. Vandesompele, and C. T. Wittwer. 2009. The MIQE guidelines: Minimum information for publication of quantitative real-time PCR experiments. Clin. Chem. 55:611-622.

Capuco, A. V., D. L. Wood, R. Baldwin, K. McLeod, and M. J. Paape. 2001. Mammary cell number, proliferation, and apoptosis during a bovine lactation: Relation to milk production and effect of bST1. J. Dairy Sci. 84:2177-2187.
Cebo, C., E. Rebours, C. Henry, S. Makhzami, P. Cosette, and P. Martin. 2012. Identification of major milk fat globule membrane proteins from pony mare milk highlights the molecular diversity of lactadherin across species. J. Dairy Sci. 95:1085-1098.

Crozat, K., R. Guiton, V. Contreras, V. Feuillet, C. A. Dutertre, E. Ventre, T. P. Vu Manh, T. Baranek, A. K. Storset, and J. Marvel 2010. The XC chemokine receptor 1 is a conserved selective marker of mammalian cells homologous to mouse $\mathrm{CD} 8 \alpha^{+}$dendritic cells. J. Exp. Med. 207:1283-1292.

Domènech, A., J. Graham Raynes, E. M. Rodriguez, A. Aris, A. Bach, and A. Serrano. 2012. Recombinant expression of goat milk serum amyloid A: Preliminary studies of the protein and derived peptides on macrophage phagocytosis. Protein Pept. Lett. 19:299-307.

Eckersall, P. D., F. J. Young, A. M. Nolan, C. H. Knight, C. McComb, M. M. Waterston, C. J. Hogarth, E. M. Scott, and J. L. Fitzpatrick. 2006. Acute phase proteins in bovine milk in an experimental model of Staphylococcus aureus subclinical mastitis. J. Dairy Sci. 89:1488-1501.

Epsztejn, S., H. Glickstein, V. Picard, I. N. Slotki, W. Breuer, C. Beaumont, and Z. I. Cabantchik. 1999. H-Ferritin subunit overexpression in erythroid cells reduces the oxidative stress response and induces multidrug resistance properties. Blood 94:3593-3603.

Farr, V. C., K. Stelwagen, L. F. Cate, A. J. Molenaar, T. B. McFadden, and S. R. Davis. 1996. An improved method for the routine biopsy of bovine mammary tissue. J. Dairy Sci. 79:543-549.

Faucon, F., E. Rebours, C. Bevilacqua, J. C. Helbling, J. Aubert, S. Makhzami, S. Dhorne-Pollet, S. Robin, and P. Martin. 2009. Terminal differentiation of goat mammary tissue during pregnancy requires the expression of genes involved in immune functions. Physiol. Genomics 40:61-82.

Gray, C., Y. Strandberg, L. Donaldson, and R. L. Tellam. 2005. Bovine mammary epithelial cells, initiators of innate immune responses to mastitis. Aust. J. Exp. Agric. 45:757-762.

Green, K. A., and C. H. Streuli. 2004. Apoptosis regulation in the mammary gland. Cell. Mol. Life Sci. 61:1867-1883.

Grönlund, U., C. Hallen Sandgren, and K. Persson Waller. 2005. Haptoglobin and serum amyloid A in milk from dairy cows with chronic sub-clinical mastitis. Vet. Res. 36:191-198.

Heid, H. W., and T. W. Keenan. 2005. Intracellular origin and secretion of milk fat globules. Eur. J. Cell Biol. 84:245-258.

Hellemans, J., G. Mortier, A. De Paepe, F. Speleman, and J. Vandesompele. 2007. qBase relative quantification framework and software for management and automated analysis of real-time quantitative PCR data. Genome Biol. 8:R19.

Hisano, S., Y. Sasatomi, Y. Kiyoshi, and S. Takebayashi. 2001. Macrophage subclasses and proliferation in childhood IgA glomerulonephritis. Am. J. Kidney Dis. 37:712-719.

Huston, G. E., and S. Patton. 1990. Factors related to the formation of cytoplasmic crescents on milk fat globules. J. Dairy Sci 73:2061-2066

Itoh, K., K. Okubo, H. Utiyama, T. Hirano, J. Yoshii, and K. Matsubara. 1998. Expression profile of active genes in granulocytes. Blood 92:1432-1441.

Janssen, M. M., and P. Walstra. 1982. Cytoplasmic remnants in milk of certain species. Neth. Milk Dairy J. 36:365-368.

Khaled, W. T., E. K. C. Read, S. E. Nicholson, F. O. Baxter, A J. Brennan, P. J. Came, N. Sprigg, A. N. J. McKenzie, and C. J. Watson. 2007. The IL-4/IL-13/Stat6 signalling pathway promotes luminal mammary epithelial cell development. Development 134:2739-2750.

Krappmann, K., R. Weikard, and C. Kühn. 2012. Evaluation of a replacement method for mammary gland biopsies by comparing gene expression in udder tissue and mammary epithelial cells isolated from milk. Res. Vet. Sci. 93:970-974.

Kusakabe, T., M. Maeda, N. Hoshi, T. Sugino, K. Watanabe, T. Fukuda, and T. Suzuki. 2000. Fatty acid synthase is expressed mainly in adult hormone-sensitive cells or cells with high lipid metabolism and in proliferating fetal cells. J. Histochem. Cytochem. 48:613622 . 
Kushner, I., M. Ganapathi, and D. Schultz. 1989. The acute-phase response is mediated by heterogeneous mechanisms. Ann. N. Y. Acad. Sci. 557:19-30.

Larson, M. A., A. Weber, A. T. Weber, and T. L. McDonald. 2005. Differential expression and secretion of bovine serum amyloid A3 (SAA3) by mammary epithelial cells stimulated with prolactin or lipopolysaccharide. Vet. Immunol. Immunopathol. 107:255-264.

Lee, C. S., F. B. Wooding, and P. Kemp. 1980. Identification, properties, and differential counts of cell populations using electron microscopy of dry cows secretions, colostrum and milk from normal cows. J. Dairy Res. 47:39-50.

Lee, M., H. Kim, D. Jeon, I. Hwang, B. Choi, K. Myung, Y. Choi, S. Paik, and M. Baik. 1996. Iron metabolism-related genes and mitochondrial genes are induced during involution of mouse mammary gland. Biochem. Biophys. Res. Commun. 224:164-168.

Lemay, D. G., D. J. Lynn, W. F. Martin, M. C. Neville, T. M. Casey, G. Rincon, E. V. Kriventseva, W. C. Barris, A. S. Hinrichs, and A. J. Molenaar. 2009. The bovine lactation genome: Insights into the evolution of mammalian milk. Genome Biol. 10:R43.

Lemay, D. G., M. C. Neville, M. C. Rudolph, K. S. Pollard, and J. B. German. 2007. Gene regulatory networks in lactation: Identification of global principles using bioinformatics. BMC Syst. Biol. $1: 56-80$.

Maningat, P. D., P. Sen, M. Rijnkels, A. L. Sunehag, D. L. Hadsell, M. Bray, and M. W. Haymond. 2009. Gene expression in the human mammary epithelium during lactation: The milk fat globule transcriptome. Physiol. Genomics 37:12-22.

Maningat, P. D., P. Sen, A. L. Sunehag, D. L. Hadsell, and M. W. Haymond. 2007. Regulation of gene expression in human mammary epithelium: Effect of breast pumping. J. Endocrinol. 195:503-511.

McDonald, T. L., M. A. Larson, D. R. Mack, and A. Weber. 2001. Elevated extrahepatic expression and secretion of mammary-associated serum amyloid A 3 (M-SAA3) into colostrum. Vet. Immunol. Immunopathol. 83:203-211.

McManaman, J. L., T. D. Russell, J. Schaack, D. J. Orlicky, and H. Robenek. 2007. Molecular determinants of milk lipid secretion. J. Mamm. Gland Biol. Neoplasia 12:259-268.

Medrano, J. F., G. Rincon, and A. Islas-Trejo. 2010. Comparative analysis of bovine milk and mammary gland transcriptome using RNA-seq. Abstract 0852 in 9th World Congr. Genet. Appl. Livest. Prod., Leipzig, Germany. Gesellschaft für Tierzuchtwissenschaften e.V., Neustadt, Germany.

Mitterhuemer, S., W. Petzl, S. Krebs, D. Mehne, A. Klanner, E. Wolf, H. Zerbe, and H. Blum. 2010. Escherichia coli infection induces distinct local and systemic transcriptome responses in the mammary gland. BMC Genomics 11:138-154.

Molenaar, A. J., D. P. Harris, G. H. Rajan, M. L. Pearson, M. R. Callaghan, L. Sommer, V. C. Farr, K. E. Oden, M. C. Miles, R. S. Petrova, L. L. Good, K. Singh, R. D. McLaren, C. G. Prosser, K. S. Kim, R. J. Wieliczko, M. H. Dines, K. M. Johannessen, M. R. Grigor, S. R. Davis, and K. Stelwagen. 2009. The acute-phase protein serum amyloid A3 is expressed in the bovine mammary gland and plays a role in host defence. Biomarkers 14:26-37.

Naylor, M. J., S. R. Oakes, M. Gardiner-Garden, J. Harris, K. Blazek, T. W. Ho, F. C. Li, D. Wynick, A. M. Walker, and C. J. Ormandy. 2005. Transcriptional changes underlying the secretory activation phase of mammary gland development. Mol. Endocrinol. 19:1868-1883.

Oliveros, J. C. 2007. VENNY: An interactive tool for comparing lists with Venn diagrams. Accessed May 22, 2012. http://bioinfogp.cnb. csic.es/tools/venny/index.html.

Paape, M. J., K. Shafer-Weaver, A. V. Capuco, K. Van Oostveldt, and C. Burvenich. 2000. Immune surveillance of mammary tissue by phagocytic cells. Adv. Exp. Med. Biol. 480:259-277.

Pisoni, G., P. Moroni, S. Genini, A. Stella, P. J. Boettcher, P. Cremonesi, L. Scaccabarozzi, E. Giuffra, and B. Castiglioni. 2010. Differentially expressed genes associated with Staphylococcus aureus mastitis in dairy goats. Vet. Immunol. Immunopathol. 135:208217.
Rainard, P., A. Fromageau, P. Cunha, and F. B. Gilbert. 2008. Staphylococcus aureus lipoteichoic acid triggers inflammation in the lactating bovine mammary gland. Vet. Res. 39:52.

Rainard, P., and C. Riollet. 2006. Innate immunity of the bovine mammary gland. Vet. Res. 37:369-400.

Rinaldi, M., R. W. Li, D. D. Bannerman, K. M. Daniels, C. Evock-Clover, M. V. Silva, M. J. Paape, B. Van Ryssen, C. Burvenich, and A. V. Capuco. 2010. A sentinel function for teat tissues in dairy cows: Dominant innate immune response elements define early response to E. coli mastitis. Funct. Integr. Genomics 10:21-38.

Robbins, S. H., T. Walzer, D. Dembélé, C. Thibault, A. Defays, G. Bessou, H. Xu, E. Vivier, M. L. Sellars, P. Pierre, F. R. Sharp, S. Chan, P. Kastner, and M. Dalod. 2008. Novel insights into the relationships between dendritic cell subsets in human and mouse revealed by genome-wide expression profiling. Genome Biol. 9:R17.

Rossi, S., and M. Loda. 2003. The role of the ubiquitination-proteasome pathway in breast cancer: Use of mouse models for analyzing ubiquitination processes. Breast Cancer Res. 5:16-22.

Rota, A. M., C. Gonzalo, P. L. Rodriguez, A. I. Rojas, L. Martin, and J. J. Tovar. 1993. Somatic cell types in goats milk in relation to total cell count, stage and number of lactation. Small Rumin. Res. 12:89-98.

Rudolph, M. C., J. L. McManaman, L. Hunter, T. Phang, and M. C. Neville. 2003. Functional development of the mammary gland: Use of expression profiling and trajectory clustering to reveal changes in gene expression during pregnancy, lactation, and involution. J. Mammary Gland Biol. Neoplasia 8:287-307.

Rudolph, M. C., J. L. McManaman, T. Phang, T. Russell, D. J. Kominsky, N. J. Serkova, T. Stein, S. M. Anderson, and M. C. Neville. 2007. Metabolic regulation in the lactating mammary gland: A lipid synthesizing machine. Physiol. Genomics 28:323-336.

Sarikaya, H. 2006. Somatic cell populations in milk: Importance in mammary gland physiology and behaviour during technological processing. PhD Thesis. Technische Universität München, Munich, Germany.

Schatzmann, F., R. Marlow, and C. H. Streuli. 2003. Integrin signaling and mammary cell function. J. Mammary Gland Biol. Neoplasia 8:395-408

Schmitz, S., M. W. Pfaffl, H. H. Meyer, and R. M. Bruckmaier. 2004. Short-term changes of mRNA expression of various inflammatory factors and milk proteins in mammary tissue during LPS-induced mastitis. Domest. Anim. Endocrinol. 26:111-126.

Schroeder, A., O. Mueller, S. Stocker, R. Salowsky, M. Leiber, M. Gassmann, S. Lightfoot, W. Menzel, M. Granzow, and T. Ragg. 2006. The RIN: An RNA integrity number for assigning integrity values to RNA measurements. BMC Mol. Biol. 7:3.

Shpyleva, S. I., V. P. Tryndyak, O. Kovalchuk, A. Starlard-Davenport, V. F. Chekhun, F. A. Beland, and I. P. Pogribny. 2011. Role of ferritin alterations in human breast cancer cells. Breast Cancer Res. Treat. 126:63-71.

Sordillo, L. M., and K. L. Streicher. 2002. Mammary gland immunity and mastitis susceptibility. J. Mammary Gland Biol. Neoplasia 7:135-146.

Steel, D. M., F. C. Donoghue, R. M. O'Neill, C. M. Uhlar, and A. S. Whitehead. 1996. Expression and regulation of constitutive and acute-phase serum amyloid A mRNAs in hepatic and nonhepatic cell lines. Scand. J. Immunol. 44:493-500.

Strandberg, Y., C. Gray, T. Vuocolo, L. Donaldson, M. Broadway, and R. Tellam. 2005. Lipopolysaccharide and lipoteichoic acid induce different innate immune responses in bovine mammary epithelial cells. Cytokine 31:72-86.

't Hoen, P. A., R. Turk, J. M. Boer, E. Sterrenburg, R. X. de Menezes, G. J. van Ommen, and J. T. den Dunnen. 2004. Intensity-based analysis of two-colour microarrays enables efficient and flexible hybridization designs. Nucleic Acids Res. 32:e41.

Uhlar, C. M., and A. S. Whitehead. 1999. Serum amyloid A, the major vertebrate acute-phase reactant. Eur. J. Biochem. 265:501-523.

Upragarin, N., W. J. Landman, W. Gaastra, and E. Gruys. 2005. Extrahepatic production of acute-phase serum amyloid A. Histol. Histopathol. 20:1295-1307. 
Urieli-Shoval, S., P. Cohen, S. Eisenberg, and Y. Matzner. 1998. Widespread expression of serum amyloid A in histologically normal human tissues: Predominant localization to the epithelium. J. Histochem. Cytochem. 46:1377-1384.

Vandesompele, J., K. De Preter, F. Pattyn, B. Poppe, N. Van Roy, A. De Paepe, and F. Speleman. 2002. Accurate normalization of real-time quantitative RT-PCR data by geometric averaging of multiple internal control genes. Genome Biol. 3:research0034.

Vangroenweghe, F., W. Van den Broeck, A. De Ketelaere, H. van Bree, L. Duchateau, and C. Burvenich. 2006. Endoscopic examination and tissue sampling of the bovine teat and udder cistern. J. Dairy Sci. 89:1516-1524.

VanKlompenberg, M. M. K., H. F. McMicking, and R. C. Hovey. 2012. Technical note: A vacuum-assisted approach for biopsying the mammary glands of various species. J. Dairy Sci. 95:243-246.

Wang, M., S. Master, and L. Chodosh. 2006. Computational expression deconvolution in a complex mammalian organ. BMC Bioinformatics 7:328-354.

Weber, A., A. T. Weber, T. L. McDonald, and M. A. Larson. 2006. Staphylococcus aureus lipoteichoic acid induces differential expression of bovine serum amyloid A3 (SAA3) by mammary epithelial cells: Implications for early diagnosis of mastitis. Vet. Immunol. Immunopathol. 109:79-83.
Whitehead, A. S., M. C. De Beer, D. M. Steel, M. Rits, J. M. Lelias, W. S. Lane, and F. C. De Beer. 1992. Identification of novel members of the serum amyloid A protein superfamily as constitutive apolipoproteins of high density lipoprotein. J. Biol. Chem. $267: 3862-3867$.

Wickramasinghe, S., G. Rincon, A. Islas-Trejo, and J. F. Medrano. 2012. Transcriptional profiling of bovine milk using RNA sequencing. BMC Genomics 13:45.

Wilson, T. C., C. J. Bachurski, M. Ikegami, A. H. Jobe, and S. G. Kallapur. 2005. Pulmonary and systemic induction of SAA3 after ventilation and endotoxin in preterm lambs. Pediatr. Res. 58:1204-1209.

Wooding, F. B. P. 1971. The mechanism of secretion of the milk fat globule. J. Cell Sci. 9:805-821.

Wooding, F. B. P., M. Peaker, and J. L. Linzell. 1970. Theories of milk secretion: Evidence from the electron microscopic examination of milk. Nature 226:762-764.

Zheng, J., A. D. Watson, and D. E. Kerr. 2006. Genome-wide expression analysis of lipopolysaccharide-induced mastitis in a mouse model. Infect. Immun. 74:1907-1915. 